\title{
Rimpu and Symbolization of Female Identity in Bima Community
}

\author{
Risca Ariska Ramadhan \\ Postgraduate English Department \\ Mataram University \\ Mataram, Indonesia \\ Riscaariskaramadhan@gmail.com
}

\begin{abstract}
This study discusses about the symbolic meaning of rimpu as a symbol of female identity in Bima community. The study focuses on Bima community especially in Donggo village. The subjects of the study were religion leaders, society leaders, and native people of Bima community. The data are collected through observation, identification, note taking, recording and interview to know how rimpu is used as the symbol of female Identity. The data will be analyzed by descriptive qualitative. It is means that done by words. The Further, I used descriptive and qualitative method where The results show that rimpu is a typical female fashion using traditional Sarong product as a material. Rimpu is a symbol of female identity in Bima community. This study also finds the important points regarding how rimpu culture acts in building the symbolizationof female identity. Thus, there are two kinds of rimpu, namely Rimpu Mpida and Rimpu Colo .Rimpu Mpida is the identity of a woman who is not married who should not show her face. Meanwhile Rimpu Colo is identity of women who are allowed to show the entire face. This model is also often called the veil special of Bima community.
\end{abstract}

Keywords-Rimpu culture; symbolization; identity; Bima, female fashion

\section{INTRODUCTION}

Indonesia is a country that has variety of languages, religions, cultures, customs, beliefs, traditions. West Nusa Tenggara is one of province in Indonesia which as a unique culture is West Nusa Tenggara. West Nusa Tenggara is one province that is famous with religious place where there are lots of mosques there. People call it "one thousand mosques". West Nusa Tenggara is one of the Halal tourism destinations in the world. It becomes one of the strong points of goverman to introduce the diversity of the region. West Nusa Tenggara consists of Lombok Island and Sumbawa. The majority of the populations of West Nusa Tenggara are Moslem. West Nusa Tenggara has some tribes such as Sasak, Samawa (Sumbawa) and Mbojo (Bima)

West Nusa Tenggara is not only famous with mosques but it also has unique culture and especially unique costume/clothes. For example in Bima there is traditional costume that becomes special clothes in Bima.

Bima is a city in West Nusa Tenggara, specifically in Sumbawa Island. There are there are three parts of Sumbawa Island such as Sumbawa village, Dompu village and Bima village. They have different languages and different cultures. Ethnic group is actually a term that is used to refer to a wide variety of groups who might share a language, historical origins, religion, identification with a common nation-state, or cultural system (Lustig and Koester 1999, pp. 33-36). Bima has a unique culture that can only be found when people go there. This culture is the symbol of female identity in Bima community.

According to Hofstede (1994, p. 5), culture is the collective programming of the mind which distinguishes the member of one group of category of people from another. In addition, bima has famous culture there, most people know about Bima culture that is traditional clothes. Every region has different culture, such as customs, language, events, food and drink, clothes, etc. Culture is that complex whole which includes knowledge, belief, art, morals, law, custom, and any other capabilities and habits acquired by man as a member of society (Avruch 1998, p. 6). West Nusa Tenggara have some regions that have own special clothes, such as; Sasak is famous for its own clothes namely lambung and pegon Meanwhile, Sumbawa is famous for amung and pene clothes. The last region is Bima that which has unique clothes namely "Rimpu”.

Bima community is famous for their own unique clothes. They are a group of people who predominantly embrace the Islamic religion that has been inherited by the ancestors from ancient time. They can be known as a society having belief in the teaching of Islamic religion. So in early time those people used "tembenggoli" (special fabric sarong of Biima as a head covering that was used instead of the hijab. Rimpu (veil) is a cover for head. "That is familiar with by which women cover themselves, their hair, face and neck. The veil as a symbol of Moslem women's social role is often used as an argument in attempts to prove of Moslem societies and Islam as a whole, and as a proof of failure of their modernization.

Rimpu began to be known as Bima culture in the 1920s which at that time only worn by women in Rasana'e (a village of Bima. Rimpu in the $18^{\text {th }}$ to $20^{\text {th }}$ centuries was only worn by Malay woman when begin to be worn by Bima women, who were the children of 'lebe' (imam ulama). Therefore the use of rimpu began to spread in various surrounding areas. Rimpu is usually worn by woman when traveling or going out from their houses as clothes covering their head and face. Every person in Bima believes that Rimpu has positive effect on woman as a cover of woman themselves. It is equal to modern hijab in this time, which is to protect ourselves But at this 
moment the culture of rimpu is like an old culture, in which people used it only at certain moment because in this time culture is develops very quickly. I think it is important for the next generation to know or to learn more about their culture to make them respect their own culture. Meanwhile this is modern time, they should know, be aware of and respect their culture despite the influence of new culture or the effect of modernization, they must respect our culture and proud of having a culture that function as symbolization of female identity, especially in Bima community.

\section{LITERATURE REVIEW}

\section{A. Rimpu}

Rimpu is a culture from Bimanase. Rimpu is traditional clothes of Bimanese culture. People called it "rimpu tembe". It means that, the use of unique sarong from Bima as clothes covering he from head and all her body. Rimpu is a way of dressing of Bima community hat using a typical sarong of Bima. Rimpu is also a series of clothes using two sheets of sarong Mbojo. Both sheets of sarong Mbojo are used on the head to cover face and at the bottom as a dress. (M.Hilir Ismail 2005).Rimpu has characteristics that different from other place. Rimpu tradition is called "sarimpu" means the use of Bima sarong to cover all part of woman's her body.

Rimpu is a culture in fashion of Biima society. Rimpu is the way of dressing that contains the specific value that is in line with local condition of the nuance of Islam.

Actually Rimpu is a traditional dress typical of Bimanese which can until now still be found in several place in Bima especially in Donggo Village. Rimpu in general consists of two kinds; which people called it RimpuMpida and RimpuColo". These kinds of rimpu look like veil but there are some differences between rimpu and veil.Also there is different way to use rimpu. However, it has the same purpose and benefits to female identity that should cover all of her body except face for female who have married. For female who is not marriage it is the best way for her to protect herself from any disruption. Rimpu is how a woman dresss in Bima, using sarong to cover the head and body, so face is the only part which is able to be seen or even only the eyes. (Malik Hasan Mahmud, 2009). The point is that Rimpu is clothing made of two pieces of sarong that aims to cover all parts of the body.

In this case, based on statements above the author describe rimpu as an identity of Bima clothes that aims to cover all of women's body and be used as female identity who should cover all their body before marriage or to avoid any danger from hose who do not belong to her family.

\section{B. Symbolization}

A symbol is something that stands in for or represents something else. In this case the symbol we use stand in for something else, like a physical object or an idea. Symbolism occurs when something that has one meaning is used to represent something entirely different. An example wearing rimpu as symbolization of identity of Bima community. Sometimes rimpu isa symbolic in a organization. Louis (1983) asserts that organization can be viewed as "culture-bearing milieu", containing a set of common norms for action, and language and other symbolic vehicles for expressing the commonalities. According to Peters (1978) Symbols as a tool that could, and should, be used to affect change in organization.

\section{Identity}

Identity is determining who or what a person or thing is. It means that who a person is or the quality of a person or group makes them different from others. Identity refers to personal characteristics or attribute someone society that are different from others the term. "identity" refers to the ways in which individual and collectivities are distinguished in their social relations with others individuals and collectivities, Jenkins (1996).

Identity means a characteristic of a person or group of people where has similarities, for example have the same clothes, such as rimpu as identity of bima community. People can identify her/him through the identity that they use. for example they are different from others because of their unique style. Actually every person has an identity. For example when someone uses rimpu, another people from another area easily guess that the person is from Bima community because only in Bima community we can find rimpu. Also identity makes people easy to identify who or what a person is.

Personal identity is concept you develop about yourself that evolves over the course of your life that may include aspects of your life. Identity helps people around us now who we are, with identity we can know the characteristics of others. An example is identity concerning their habit, custom, or their clothes.

\section{METHOD}

The data of this paper are collected by applying some techniques; observation, identification, note taking, recording and interview. Data consist of excerpts from documents captured in a way that records and preserves context. After the researcher observation the data and continue with identification is there has symbolization of female identity. Then, the purpose of making note is to facilitate the real of data that is obtained in order to remain sequentially in accordance with the real situation. Recording and interview is the last steps to collect the data. This study focuses on the symbolic meaning of rimpu as a symbol of female identity in Bima community.

This study focuses on Bima community especially in Donggo village. The samples of the data are religion leaders, society leaders, and native people of Bima community who live in Donggo Village for a long time. The participants are from different levels of status, age and educations. The data are analyzed by descriptive qualitative method to reveal the symbolization of female identity in Bima community. According to Huberma Miles (1994: 01) Qualitative method is a research procedure that produces descriptive data in the form of words written or spoken about the properties of an individual, the state or the symptoms of a particular group can be observed.

Bodgan and Biklen (1982, p. 27) mention characteristics of qualitative research as follows: 
1) Descriptive, as data collected are in form of words or picture rather than number.

2) Inductive data in which the researcher does not search out data or evident to prove or disapprove hypothesis.

Based on the definition about qualitative research this research is categorized into qualitative research because the data are in the form of utterances and words.

According to (Miles and Huberman (1994) there are three components to analyze the data, namely:

\section{1) Data reduction}

Data reduction refers to the process of selecting, focusing, simplifying, abstracting, and transforming the data that appear in the written-up field notes or transcription (Huberman Miles, 1994, p. 10).

In data reduction stage the researcher focused on the data important for the analysis and eliminates other elements which are not important. Therefore, the data reduction gives clear description, so that the researcher was easy to find the data needed.

\section{2) Data display}

Data display is the next step after data reduction. The qualitative approach, the data display is done in short essay. Miles and Huberman state that "the most frequent of displaying data for qualitative research data in the past has been narrative text". Data display is an organized, compressed, assembly of information that permits conclusion drawing and action

\section{3) Conclusion drawing and verification}

The third stage of analysis activity is conclusion drawing and verification is processed or transferred into forms that fit the pattern of problem solving is done (Huberman Miles, (1994, p. 10-11).

The data were analyzed by combining the context and situation. Then the researcher interviewed samples of the data, such as religion leaders, society leaders, and native people of Bima community.

\section{RESUlT AND DISCUSSION}

After analyzing the data the result shows that; rimpu is a typical female fashion which uses traditional Sarong product as a material. Rimpu is a symbol of female identity in Bima community. This study also finds the important points regarding how rimpu culture as symbolization of female identity. Thus, there are two kinds of rimpu, namely rimpu mpida and rimpu colo.

Rimpu mpida is the identity of woman who is not married who should not show her face. Meanwhile rimpu colo is the identity of woman who are married who are allowed to show the entire face. This model is also often called the veil special to Bima community.

The first type is Rimpu Mpida. It uses tembe nggoli (sarong Bima) that is worn by mbojo woman (BimanesE Woman) who are not married to avoid the temptation and slander which is cover part of her face. It leaves only eyes which are able to be seen (a kind of veil that wear for Islamic woman) (M. Hillir Ismail \&Nyonya Si Linda 2007, p. 35). In addition, rimpu reflects the status or identity of woman in a community. The tradition of Bima society, woman who are still not marriage are not allowed to show her face, but in this case, it does not means that limits her motion. A woman can do everything she wants.

Second type is Rimpu Colo. This type is intended for women who are married. It means that, they are allowed to show her face. But sometimes those are nor marriage also use rimpu colo.

Actually women should follow the culture that has long been there The existence of differences between the use of "rimpu" between the woman who have married indirectly explains to the public, especially about the identity of woman itself, whether they are married or they are still single. In this case, rimpu becomes symbolization of female identity.

However, the effect of modernization, rimpu culture will be lost if it is not preserved by local community (Bima community). There are way how government to preserved the tradition. For example is the use of rimpu in "sangiang mount" event at Bima especially in Wera Village. It is the same as Tambora mount" event in Dompu, that many people in Bima especially people from different place who followed the celebrates of these event or the others event in Bima is usually used rimpu. Those events are actually aimed to introduce the Bimanese culture especially the traditional clothes of rimpu as symbolization of female identity in Bima community.

In modern era the existence of rimpu is almost forgotten. Because this time, hijab become trend favorite trend in the society. There are many kinds of hijab that become trend now, such as hijab syar'i In this case, people who wear rimpu are difficult to find. We can found Bima community who wear rimpu especially in Donggo Village.

Because of modernization, it is difficult to find people who wear rimpu. Actually long time ago, people wore rimpu in their daily activities. No matter where they wanted to go, no matter what they were doing. They still wear rimpu as their daily clothes. Because rimpu made them comfortable and feel protected from the sun and also from the male are not their families. They believed when they wore rimpu they would protect her. Actually they should not forgot their culture, because with their culture actually give their symbolism that they are Bima society. In this case, we cannot only judge whether they should wear it or no. However it all depends on each individual does still care about her culture or not.

\section{CONCLUSION}

Indonesia is a country that has some unique variety of language, religion, culture, customs, belief, tradition. West Nusa Tenggara as one province that familiar with religious place, where there are lots of mosques there. West Nusa Tenggara is one of Halal tourism in the world. It becomes the one power of government to introduce variety of there. It consists of Lombok Island and Sumbawa. Actually West Nusa Tenggara majority of the population in Muslim. 
Bima is a city in West Nusa Tenggara, especially in Sumbawa Island. There are three part of Sumbawa Island namely Sumbawa village, Dompu village and Bima village. They have different languages and different cultures. Bimanese has unique tradition clothes, that is Rimpu.

Rimpu is traditional clothes of Bimanese culture. People call it "rimpu tembe". It means that, the use of unique sarong from Bima as clothes covering the head and face under the bottom of her body. This study found that there are two kinds of rimpu in Bima community namely rimpu mpida and rimpu colo. Rimpu mpida is worn by women who are not marriage and rimpu colo is wear by women who are married We can use people who still wear impu in Bima community especially in Donggo illage or we can find people who wear rimpu in big events such as sangiang in Bima and Tambora event.

Actually rimpu is traditional clothes of Bimanese and one of the favorite clothes. Because it is not only as a pride of bimanese, it also becomes a good value for Bimanese people when wearing it. Because wearing rimpu is like wearing a veil which covers all of the body of female. It covers from head until bottom body parts ranging from head to the lower parts of the body.

Generally, Bimanese female wear rimpu to cover their body as teaching Islam teach that every single woman should cover her body to protect herself in front of people that not her family or the other words people or men who not become as partner life. so in this case, rimpu is a tool to covering and to protect herself from every disruption and it is became the one famous clothes ever in Bima and become an symbolization of female identity of Bima community especially in Donggo Village.

From time to time, the culture of rimpu is gradually forgotten. Actually woman in Bima are lack of awareness to preserve their culture. As we know an awareness of their culture is very important for their family also for next generation. The point is woman keep in mind their culture and should not be forgotten.

Sometimes Bima societies wear rimpu when there are big events or some occasions in society. The reason why they begin to forget his culture is that there is modernization that is hijab fashion. As we know that people usually finds the new trends namely Hijab or modern hijab. It means that Bima society wear hijab to substitute rimpu. There are many kinds of hijab that they have. They switch to wearing veil with current fashion trends. And they only think that rimpu is old fashioned and is not suitable with the era.

So in this case, there are some places that can be found who still wearing rimpu such as palibelo, rasana'e, and especially in Donggo Village. We can conclude that rimpu has points, such as; moral value, social politeness, and religious value.

Indeed, there is no reason not to protect the culture. We as the next generation should think positively about the importance of a culture. In addition the government should think about the importance of rimpu itself. In this case, the government should hold a variety of cultural activities in order to preserve the cultural festivals.

Rimpu also makes woman comfortable and feel protected from the sun and also men who are not her family. They believe when they wear rimpu they will protect her. Actually they should not forget their culture, because their culture actually acts as symbolism that they are Bima society. In this case, we cannot only judge whether they should wear it or not. It depends on each individual, whether she still care about her culture or not.

They can start to introduce the tradition sarong Bima in the world. It is the best way to introduce their culture to the world. It will increases revenue cottage industry sector especially tradition woven Bima. As we know, the identity of Bima is their traditional fabric and the unique colors of the fabric. The government of there should give socializations to the society about that important of preserving their culture because as can be seen in this time rimpu is almost forgotten.

As we know globalization has cut walls between cultures. Globalization is also a construct that combines the culture of mankind in one great culture. Sometimes, they always want to imitate the style and behavior of other nations by eliminating the identity of its own people (mistaken identity).

Actually, people call a "culture" when a group of people have habit or custom in that group/society. A culture is the characteristic and knowledge of a particular of people.

\section{References}

Avruch, K. (1998). Culture and conflict resolution. Washington DC: United States Institute of Peace Press.

Bodgan, C and Biklen, Knopp. (1982). Qualitative research for education introduction to theory and method. Boston: Allyn \& Bacon.

Hilir, M. (1980). Sejarah Bima dalam perjuangan kemerdekaan. Jakarta: Lengge.

Hilir, M \& Nyonya Siti Linda Yuliarti. (2007). Seni budaya mbojo. Bogor: Binasti.

Hofstede, G. (1991/1994). The cultures and organization: software of the mind. London Harper Collins Business.

Jenkins, Richard. (1996). Social identity. London: Routledge.

Louis, M. R. (1983). Organization as culture-bearing milieu.In L.W. Pondy. P. J. Frost, G. Morgan, \& T. C. Dandridge (Eds.), Organizational Symbolism (pp. 39-54). Greenwich, CT: JAI Press.

Malik Hasan Mahmud. (2009). Gusu waru. Mataram: Lengge Press.

Miles, M. B. and Huberman, M. (1994). A qualitative analysis: an expanded sourcebook. Thousand Oaks, CA: Sage.

Peters, T. J. (1978). Symbols, patterns, and settings: An optimistic case for getting things done. Organization Dynamics, 3-23. 